\title{
Process Management in Football Youth Development Program
}

\author{
Serdar Samur \\ Correspondence: Serdar Samur, 13928 Mennonite Pt. San Diego,CA., 92129, USA. \\ Received: June 12, 2019 \\ Accepted: June 23, 2019 \\ Online Published: June 25, 2019 \\ doi:10.11114/jets.v7i9.4342 \\ URL: https://doi.org/10.11114/jets.v7i9.4342
}

\begin{abstract}
In our age, businesses are accepted as living organisms. Businesses that are aware of this change have begun to transition from a result-oriented work system to process management, closely following customer expectations in order to exist in the future as well. The largest expense that sports clubs incur involves transfer spending, because the most talented footballer, who would influence team success, is recruited from outside the club. Today, many sports clubs are incorporated and need to create their own economic resources that would not only ensure their survival but also their success and continuity. This resource can be achieved by means of the footballers who participate in the youth development programs conducted by the club' football academy. The standards of football are on the rise, and so are the expectations of all those involved, with qualified footballers demanding astronomical wages. Sport clubs need to increase their profits by using the resources that are being developed in their respective football academies. If a given footballer attains a high standard by performing well during training and making it to the first string team, the club has to save on the transfer budget. The aim of this study is to determine how club football schools and academies manage in accordance with process management within the system approach. This study incorporated the qualitative research method and case study technique. Data was collected with the help of the interview technique and examined using content analysis. In this research, it was found that youth development programs should be managed by employing three main processes: covering education in sports schools, practicing with competitor teams, and transitioning to professionalism. If these processes are applied across football academies, it would lead to the emergence of economically qualified footballers. Youth Development Programs, as a part of the system of process management within the framework of organizational structures of sports clubs, will prove to be an ideal form of structuring.
\end{abstract}

Keywords: process management, youth development, training, performance, productivity

\section{Introduction}

The most vital issue for each professional club is to make a good team-skeleton and its continuity to make an ongoing investment. (Ferguson and Moritz, 2013) The good team will bring sportive success and that leads to the appreciation of the brand and the increase in the number of fans, thus giving the opportunity to get more economic resources from the football market (Samur, 2013)

The most important expense item of sports clubs is the transfer budget. The most important criterion in the transfer is to provide the footballers with the right qualifications and the right price at the right time to the positions required by the professional team (Devecioğlu, 2018).

The criteria cannot always be fulfilled economically because qualified players are provided by transfer from other clubs, not from the football academies within their own organization in Turkish Football clubs (Akşar, Kutlu and Devecioğlu, 2018).

Constantly trying to make the best transfer by borrowing from banks is not sustainable in today's contemporary club management because the most basic income source for clubs are well-trained, qualified footballers in their football academies (Akşar, 2013).

The lack of scientific research on how Sports Clubs will structure football academies in accordance with the requirements of the era is the subject of this research.

Football is a subject of research in many fields of sports science. These include sports and health sciences, movement and training sciences, psycho-social fields in sports, physical education and sports teaching (Eniseler, 2010). Football, which has such a close relationship with sports sciences, is also a sports branch with very different characteristics such as Technical, Tactical, Conditional, Psychological, Health, and nutrition (Kale, 2017) 
Football coaches take into account the basic physiological requirements of football and the physical strength of the footballer. Once a physical assessment is made, they set up a calendar for development planning (Balyi, 2002) That is, it is necessary to know which physiological properties are required to develop different types of activities.

The football game has a structure that requires different speed and movement, which requires long and complex physical-physiological characteristics in terms of activity quality and playing time. (Strudwick and Reilly, 2001)

Besides these; There are activities such as slipping, falling and standing up, sudden direction change, making many movements in succession with fast and quick rotation movements that require great muscular force, strength, and durability. These different movements; In the equation of speed and accuracy, it is necessary to fulfill the physiological requirements of those movements in order to continue throughout the match (Rienzi, Drust, Reilly, Carter and Martin, 2000)

Strength and endurance training promotes specific neuromuscular and cardiovascular adaptations. The adaptations induced by strength training include muscle hypertrophy increase in the motor unit recruitment capacity and motor unit firing rate. These neuromuscular adaptations result in improved muscle strength and power development. (Chtara, Chamari, Chaouachi, Chaouachi, Koubaa, Feki, and Amri, 2005).

Myer et al. (2011b) defined neuromuscular training (NT) as a training program that incorporates general (e.g., fundamental movements) and specific (e.g., sport-specific movements) strength and conditioning activities, such as resistance, dynamic stability, balance, core strength, plyometrics, and agility exercises with the goal to enhance healthand skill-related physical fitness components and to prevent injuries. According to this definition, agility, balance, plyometrics, power, stability, and strength training are subsets of NT. (Myer, Faigenbaum, Ford, Best, Bergeron, \& Hewett, 2011b)

Findings from original work, systematic reviews and meta-analyses proved the effectiveness of NT on muscular fitness, motor skills, sports performance, resistance to injuries, metabolic and mental health in non-athletic youth. (Behringer, Vom Heede, Yue, \& Mester, (2010).

Human development is an ongoing process starting from fertilization until the end of life. The ages in developmental stages vary according to different sources. In general, (Topkaya and Tekin, 2004)

- the first 2 years after birth, Infancy,

- 3-6 years of age, the First Childhood (play),

- 7-11 years of age the Second Childhood of primary school,

- 11-12 years of age, the Transition to Adolescence, and

- 12-18 years of age is considered Adolescence

The most critical development period of human life, which significantly affects the life of the individual, is defined by the World Health Organization (WHO) as the adolescent period between the ages of 10-19. Rapid physical growth and development in adolescence cause anatomical, physiological, mental and psychological changes (Bulduk, Şanlier and Demircioğlu, 2009).

The physical activity of children and adolescents between 6-18 years age is great and in order to be able to spend this age period in an effective way, the establishment of a regular and systematic structure in the football academies of sports clubs will enable both the development of a healthy generation and the training of qualified footballers who will have important economic results in case of talent detection.

Turkey Football Federation League of Youth Development is divided into two parts. The first is the Regional Development League and includes U15, U16, U17, and U19 teams, the other is the Elite League. This includes U14, U15, U16, U 17, U19 Leagues. (TFF development leagues status: www.tff.org).

Youth development training can be divided into 3 classes as Basic Building Training, Development Training and Performance Training in accordance with the developmental stages of the children ( Topkaya and Tekin, 2004).

Basic building training: According to the Turkish Football Federation (TFF) age grouping, it includes training sessions for children between 6 and 12 age. It is known that the age range for starting football is between 6 and 9 years because the physical ability of the child begins to develop best during this period. Thanks to sports, the child's physical development becomes healthier and the muscles develop (Hill, Dawson, Coutts and Rowsell, 2008).

Stafford (2005) states that the child begins to learn competition in this age range. In this period, games are mostly aimed at building the basic physiological structure. In the game, adaptation to the ball is important, not the rules.

Development Training: According to the TFF age grouping, it includes the training given to children between 12 and 16 
age. Hill-Haas, Dawson, Coutts and Rowsell (2008) state that children of this age are in a period of pre-adolescent mental and physical crisis. Growth and development cause deep changes in internal organs and functions. In terms of training, the features revealed in the basic building training section are tried to be transformed into the features desired by certain positions in this period (Eniseler, 2010)

Continuous loads should be avoided in training. Long breaks should be given to normalize the heart rate between loads. Technical studies should include play and close-to-competition forms. The use of gymnastics in training should be essential. (Topkaya and Tekin, 2004) Children and young people in this age bracket should take part in moderate to vigorous physical activities for at least 60 minutes (one hour) every day, and this can be up to several hours. Moderate intensity activity means working hard enough to raise your heartbeat, so you breathe harder and begin to sweat, but are still able to talk (www.gosh.nhs.uk).

In tactical exercises: preliminary tactical exercises can be performed by playing games according to certain simple sequences. In the studies, the game should be stopped and errors should be corrected and the heart rate of football players should be restored to normal. In defense and attack, the use of standing balls can be entered and the match tactic can be entered theoretically (Eniseler, 2010).

Non-intensive strength exercises of young people by using their own body weights at the age of 13-14 are carried out in the form of strength training using additional weight with the 15th age. However, the weight percentage in the studies should be $40 \%$ of the weight of the player himself (Bloomfield, Polman and O'Donoghue 2007).

Performance Training: After completion of basic building training, performance training starts and this process continues throughout professional life. In performance training, the physiological standards of football are tried to be reached. Other factors that affect performance are considered (Martindale, Collins and Abraham, 2007).

The training must pass in integrity (technical + tactical + condition) and tempo under match conditions. Since the footballer chooses this job as a profession, he must pay close attention to factors that directly affect the performance of his private life, such as nutrition and sleep patterns (Eniseler, 2010).

Players who have undergone academic training and have reached the age of 18 should be aware of developing their abilities after having sufficient knowledge of their physical capabilities and abilities (Ferguson and Moritz, 2013).

The sport criteria (www.uefa.com), which is among the criteria of UEFA's license: the fact that clubs make the best effort for the sportive and academic education of young people and employ competent technical trainers for this purpose indicates a system based structure.

In our age, businesses have begun to prefer the transition from the result-oriented working system to process management in order to keep pace with the change rapidly and to exist in the future. (Çetin, Akin and Erol, 2001) More precisely, constantly controlling and improving the process, and continuously making accurate results requires long-term work and stability.

Business Process Management (BPM) is a systematic approach to support the achievement of organizational objectives (Antonucci,2009, Davis, 2007, Jeston and Nelis, 2006) highlighting the importance of an overall articulation of the work to fill the business objectives.

Jeston and Nelis (2008) considered that BPM is a community of people working together, with a common goal to deliver a solution, product or service to the customers ensuring they are serviced to a high standard and leave the experience delighted. Also, the same author suggests that BPM supports the achievement of the organization objectives through the improvement, management, and control of the fundamental business processes.

Davis (2007) states that BPM is a systematic approach to managing and improving an organization business by the active, coordinated management of all aspects of the specification, design, implementation, operation, measurement, analysis and optimization of business processes in order to effectively and efficiently deliver business objectives.

BPM support business processes using methods, techniques, and software to design, enact, control, and analyze operational processes involving humans, organizations, applications, documents and other sources of information. (Aalst, 2003).

We define BPM as the management discipline that transfers strategy into execution - at pace with certainty (Franz and Kirchmer, 2012). Hence, we refer to BPM as the BPM-Discipline (BPMD). This definition shows that BPM uses the "business process" concept as a vehicle for across-organizational strategy execution, including the collaboration with market partners like customers, agents, or suppliers. (Antonucci and Goeke,2011) The execution of the strategy can be people or technology-based - or a combination of both. This definition is consistent with the newest findings in BPM-related research (Swenson, and Von Rosing, 2015).

Harmon (2011) integrated the concept of system, associating system to process, maintaining the perspective of the 
existence of inputs, developing its transformation to outputs generating value for the customer.

The system approach remains up-to-date within modern management approaches. Process management can be best implemented within the system approach. (Barton, Emery, Flood, Selsky, and Wolstenholme, 2004) More specifically, the system approach and process management support each other. (Pourdehnad and Robinson, 2001)

There are many definitions of systems in the literature, but in general, the majority has three central ideas in common (Arregui, 2001):

- $\quad$ Systems have a set of parts,

- There is an inter-relationship between these parts or elements, and

- They have a coherent pattern (i.e. common purpose or objective) ensuring that the interacting parts form the whole.

The essence of systemic thinking includes the following: understanding the inter-relationships rather than the linear cause-effect relationships; viewing the dynamic rather than the static processes and viewing and understanding the context (Skarzauskiene, 2010)

What one understands as a systemic focus, in general, includes some aspects (Mingers and White, 2010) as follows:

- Viewing the situation holistically in opposition to reductionism, that is, as a set of elements interacting within the environment.

- Recognizing that relationships or interactions between elements are more important than the elements themselves for determining the behavior of the system.

- Recognizing a hierarchy of system levels and the resulting ideas of emergent properties at distinct levels, including mutual causality among them.

More precisely, the process is a collection of businesses and activities that must be done to produce certain goods and services in enterprises. This group of businesses and activities are brought together one after the other and interdependently, producing goods and services that will increase customer satisfaction. (Ülgen ve Mirza, 2007)

The process of converting inputs into more valuable outputs is called process transformation. Doğan (2013) states that Inputs can usually be converted to four types in the process. This transformation is physical, spatial, valuable and computational.

The structuring of processes is called the process hierarchy. This hierarchy enables the depths of the vertical relations of processes to be defined. The process hierarchy is divided into 4 levels, the main processes, processes, sub-processes, and process activities. (Doğan, 2013)

- Basic Processes (8-10 pieces): These are strategic processes that have a direct impact on business outcomes and operational performance and productivity, and are important in achieving competitive advantage and achieving the objectives of the enterprise.

- Processes: Processes that are involved in the formation of basic processes and interact with each other at the same time.

- Sub Processes: Processes are processes with significant outputs that involve multiple functions in processes

- Process Activities: It consists of simple processes starting and ending in a process

The process management starts with determining the vision and objectives of the enterprise. Then a team should be formed to provide the necessary resources for the provision and improvement of the necessary activities. The selected team identifies and documents processes. Determined processes, critical success factors, and critical processes are identified. (Kirchmer, 2015) Completed processes are monitored, measured, analyzed and continuously improved. (Ewalt, 2002)

In Sport Clubs academies, it is important to know the characteristics of football in order to activate process management. Football grasps not only the Physical - Psychomotor features but also a wide range of Psychological - Cognitive Affective Characteristics. A systematic working method is needed to bring this complex structure to a controllable level and to monitor and control individual development. (Topkaya and Tekin, 2004) It is a long-term business to train highly qualified athletes with standards in football academies. The dedication of all professional staff is needed. (Balyi,2002)

The fact that football players with these characteristics can be trained in their football academies may be possible with a model that requires long-term and disciplined work. This research was conducted within the framework of Youth Development Programs of sports clubs in the Professional 1st. 


\section{Method}

\subsection{Research Method and Model}

This research was carried out in order to make football academies of sports clubs suitable for the process management and the findings were evaluated according to this purpose.

This research was conducted within the framework of Youth Development Programs of 5 sports clubs in the Professional 1st. league during the 2017-2018 season of the Turkish Football Federation. The questions were directed to 2 managers and 3 coaches who have worked in the football academies of the clubs for at least 5 years.

The research was conducted in accordance with the qualitative design. Qualitative data collection methods such as observation, interview, and document analysis are used in qualitative research. and perceptions and events are tried to be revealed in a natural environment in a realistic and holistic way. (Yıldırım and Şimşek, 2005)

\subsection{Developing the Data Collection Tool}

The data were collected through interviews with managers and coaches working in club football academies. During the meeting with the clubs, semi-structured questions were interviewed. Each of the questions is prepared to obtain different data. The interview method approach, which is one of Patton's interview approaches, was used as the interview technique. Two open-ended and semi-structured questions were prepared in advance. The questions asked to Sports Managers and Technical Men in the interview form are as follows:

- Which training model is applied in the football academy depending on the physical development of children?

- What are the main topics and sub-topics of the applied programs?

- How did you create a categorical structure as an age in the Football Academy?

- What should be done to raise football players in the age group of 6-18?

\subsection{Data Analysis}

The data were first written by the researchers in computerized form and then analyzed by using content analysis from qualitative research techniques. The answers given by the department managers to each question were grouped in terms of their similarities, In order to increase the reliability of the study, an expert's analyzes were taken into consideration and common points were determined.

\section{Results}

It is understood that youth development programs need to be integrated with the compulsory criteria of UEFA and there is a need to establish an academic structure that works with scientific methods to train elite football players who have reached the highest level of talent.

It is evident that there is a need for a program that will enable the development of the technical, tactical, motor, social and psychological abilities and anatomical structures of children and adolescents. The training management program to be established will need to be organized to implement process management within a system understanding.

Arregui (2001) says that the system is conceptually defined as an organized and indivisible whole, consisting of two or more parts or sub-systems that are dependent on each other, with a specific boundary in terms of working characteristics and differentiated from other systems or associated with the external environment from subsystems.

This understanding can be organized by dividing children into 3 main processes, 5 subprocesses, and 7 process activities in accordance with the developmental period and development leagues of children. Doğan (2013) says that the structuring of processes is called the process hierarchy and this hierarchy enables the depths of the vertical relations of processes to be defined. These statements of the author shed light on the regulation of our findings. The process hierarchy is divided into 4 levels, the main processes, processes, sub-processes, and process activities.

As a result, according to this explanation, the academic program can be divided into 3 Processes, 6 Subprocesses, and 7 Process Activities and can be arranged as follows: Table 1 (Academic Program Process) 
Table 1. Academic Program Process Chart (Main Process)

\begin{tabular}{|c|c|c|c|}
\hline Duration & Number & Stage and Age & Explanation \\
\hline Process & 1 & Training in Sports School & $\begin{array}{l}\text { This process covers the training of children and young people } \\
\text { aged } 6-12 \text { in a football school. The important thing in this } \\
\text { group is not the football itself but the child itself. This process } \\
\text { consists of two sub-processes. }\end{array}$ \\
\hline \multirow[t]{2}{*}{ Subprocess } & 1.1 & $\begin{array}{l}\text { Basic Education -I } \\
\text { The firs Childhood } \\
\text { (U6-U9 Age }\end{array}$ & $\begin{array}{l}\text { In this age range, the development of the physical abilities of } \\
\text { children should be given importance to swimming and } \\
\text { athletics from other sports branches and they should be } \\
\text { introduced to a wide range of playful forms. Trying to identify } \\
\text { the players who have talent in football. }\end{array}$ \\
\hline & 1.2 & $\begin{array}{l}\text { Basic Education-II } \\
\text { Second Childhood and } \\
\text { Adolescence } \\
\text { (U10-12 Age ) }\end{array}$ & $\begin{array}{l}\text { Player-centered training, multi-faceted sportive basic } \\
\text { movement training, coordination, and flexibility learning by } \\
\text { playing without separation, importance in football basic } \\
\text { technical training, fair play, healthy nutrition, communication } \\
\text { should be given importance. Children who are believed to } \\
\text { have talent during their education in sports schools move to } \\
\text { this section to form an elite group and try to improve their } \\
\text { ability. }\end{array}$ \\
\hline \multirow{3}{*}{$\begin{array}{l}\text { Process } \\
\text { Activity }\end{array}$} & 1.1 .1 & Age Classification & Children are classified according to age and development \\
\hline & 1.2 .1 & Talent Selection & $\begin{array}{l}\text { Initial training is the implementation of educational games } \\
\text { and Try to elite group formation. Covers talented athletes in } \\
\text { sports schools and directed to the academic structure. }\end{array}$ \\
\hline & 1.2 .2 & Basic Education Practice & $\begin{array}{l}\text { Applications will be linked to a program and will be done } \\
\text { based on the measurement and evaluation observation at the } \\
\text { age of } 12 \text {. }\end{array}$ \\
\hline Process & 2 & $\begin{array}{l}\text { Practice for Competitor } \\
\text { Teams }\end{array}$ & $\begin{array}{l}\text { This process involves the creation of competing teams within } \\
\text { the football academy and the development of qualifications in } \\
\text { teams and the transition to professionalism. This process } \\
\text { consists of three sub-processes. }\end{array}$ \\
\hline \multirow{3}{*}{ Subprocess } & 2.1 & $\begin{array}{l}\text { Transition to Expertise } \\
\text { (U13-U15 age) } \\
\text { the first period of } \\
\text { adolescence }\end{array}$ & $\begin{array}{l}\text { In this process, emphasis should be placed on the teaching of } \\
\text { the basic principles of football, In the process of development, } \\
\text { competitions should be started in leagues with specific } \\
\text { technical and tactical studies. }\end{array}$ \\
\hline & 2.2 & $\begin{array}{l}\text { Expertise } \\
\text { (U16-U18-age) } \\
\text { the last period of } \\
\text { adolescence }\end{array}$ & $\begin{array}{l}\text { The aim of the course is to develop conditional features and } \\
\text { tactical applications in the competition environment. }\end{array}$ \\
\hline & 2.3 & $\begin{array}{l}\text { Performance: } \\
\quad(\mathrm{U} 19)\end{array}$ & $\begin{array}{l}\text { Prepared for the transition to professional life. In accordance } \\
\text { with the management of training and matches, } \\
\text { importance should be given to training planning, training } \\
\text { periodization, and gaining a notion. }\end{array}$ \\
\hline \multirow{2}{*}{$\begin{array}{l}\text { Process } \\
\text { Activity }\end{array}$} & 2.1 .1 & $\begin{array}{l}\text { Ability Development } \\
\text { Programs }\end{array}$ & Educational activities are organized according to age groups. \\
\hline & 2.1 .2 & Reach the Standart & $\begin{array}{l}\text { In this process, Tournaments, Age groups, and health } \\
\text { management issues are important }\end{array}$ \\
\hline Process & 3 & $\begin{array}{l}\text { Transition to } \\
\text { Professionalism }\end{array}$ & $\begin{array}{l}\text { This process prepares the transition to professionalism. Young } \\
\text { people who have completed their standards and who have a } \\
\text { future in football will have a period in which they will be } \\
\text { prepared for the A teams. }\end{array}$ \\
\hline Subprocess & 3.1 & $\begin{array}{l}\text { Transfer to Professional } \\
\text { League }\end{array}$ & $\begin{array}{l}\text { It is thought that the footballer which has undergone academic } \\
\text { education and has reached the top level of standards is to work } \\
\text { firstly in the A teams, and if this is not possible, it will be sent } \\
\text { to lower leagues or other clubs for rent in such a way that they } \\
\text { will not be separated from professionalism and contribute to } \\
\text { the development of their performance. }\end{array}$ \\
\hline \multirow{2}{*}{$\begin{array}{l}\text { Process } \\
\text { Activity }\end{array}$} & 3.1 .1 & Transfer to Team B & $\begin{array}{l}\text { Players who cannot go directly to team A are transferred to } \\
\text { team B, the preparatory team. }\end{array}$ \\
\hline & 3.1 .2 & Transfer to Team A & $\begin{array}{l}\text { Players with advanced skills in the preparatory team and those } \\
\text { trained in U-19 are transferred to the A team. }\end{array}$ \\
\hline
\end{tabular}




\section{Academic Program Process Chart: Table 1}

When we configure the data in the table above according to a systematic understanding, we can reach the following results:

Children who started their education activities in sports schools constitute the input part of football academies. Among these inputs, children who are thought to have the ability to play football are included in academic education and training as part of process management. Harmon (2011) states that the process of converting inputs into more valuable outputs is called process transformation and Doğan (2013) states that Inputs can usually be converted to four types in the process: physical, spatial, valuable and computational. These findings are considered to be close to the author's findings.

Young people who have reached the desired standards in academic education become ready for professional life as the output of the process. Eniseler (2010) states that Football, which has such a close relationship with sports sciences, is also a sports branch with very different characteristics such as Technical, Tactical, Conditional, Psychological, Health, and nutrition. These statements of the author contributed to the determination of the general standards of education in football academies.

As a result, we can express the academic program process in accordance with the system approach as shown in figure-1 below. Determining the standards of academic education in the processing activity in close relationship with sports sciences would be appropriate.

Basic Process: Academic Program Process (Youth Development and Professionalism)

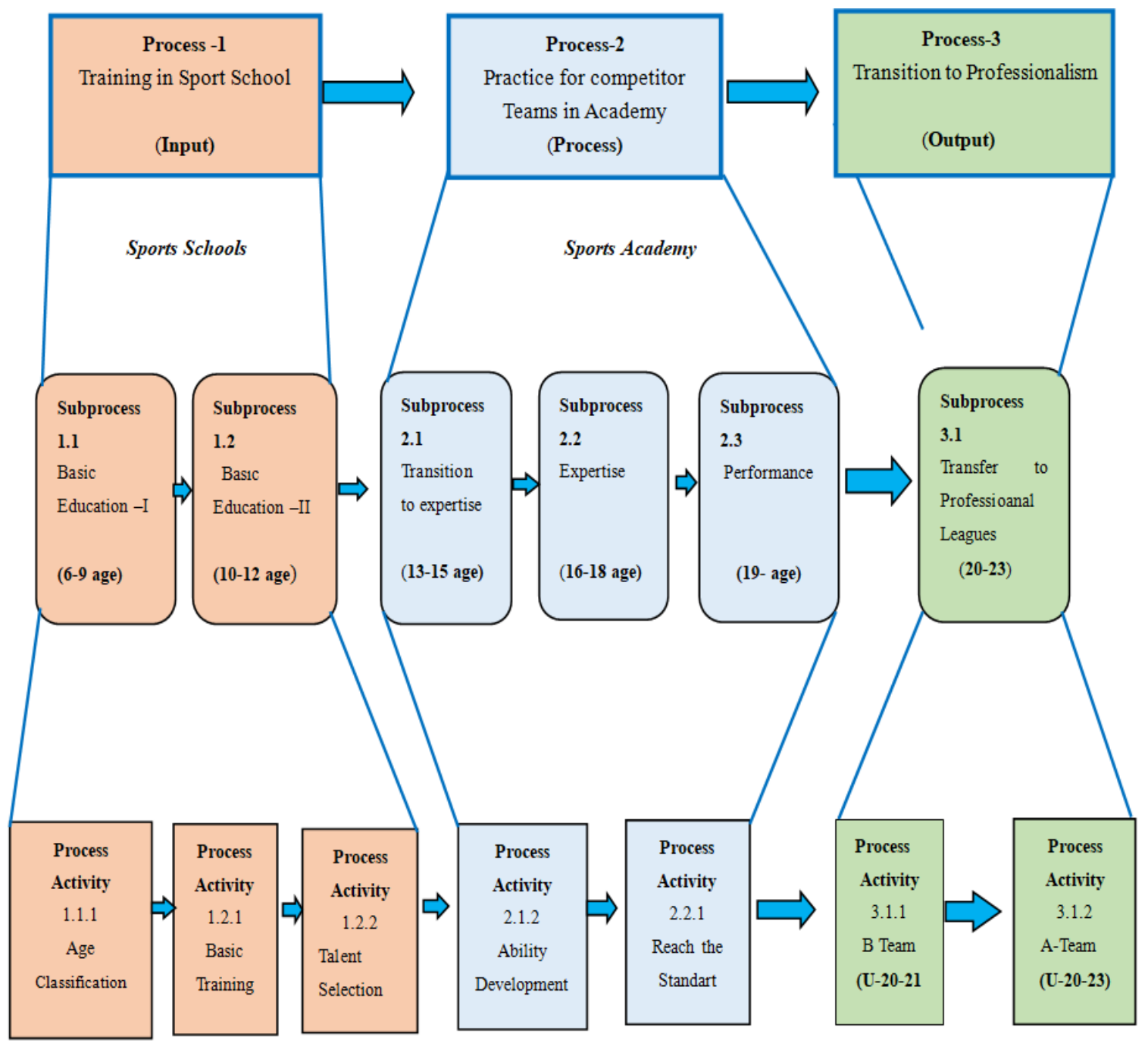

Figure 1. Basic Process and Hierarchy 


\section{Discussion}

As a result of the interviews, the codes, and themes related to the findings that will enable the organization design for the sport organization structures and the process management will be brought to the table -2 (Code and Theme) below.

\section{Code and Themes Table}

Table 2. Code and Themes

Questions
1. Which training model is
applied in the football
academy depending on the
physical development of
children?

2. What are the main topics and sub-topics of the applied programs?

3. How did you create a categorical structure as an age in the Football Academy? 4. What should be done to raise football players in the age group of 6-18?

Codes
Education in Sports Schools ;(First
Childhood)
With the development of physical
skills of children in the 6-9 Age
Range, swimming and athleticism
should be given importance from other
sports branches and should be
introduced to a wide range of playful
shapes. Providing these children who
are among the first group of club
football academies with the love of
sports with educational games,

Education in Sports Schools; (Transition to Secondary Childhood and Adolescence)

In the 10-12 Age Range, educators should give importance to player-centered training, versatile sportive basic mobility training, Coordination and flexibility, learning by playing without distinction, basic technical training in football, Fair Play, Healthy nutrition, communication.

Practice on Teams: (First Period of Adolescence) In the 13-15 age range, educators should focus on the education of the basic principles of football, and the competition should be started in the leagues with special technical and tactical studies.

Competitors Practice: (Last Period of Adolescence) In the 16-18 Age Range, educators should focus on the development of conditional features and tactical practices in the competition environment.

Preparing for Professional Life (19 Years and After) In this period, young people should be prepared for professional life as a trained football player

Transition to Professionalism

The trained players are transferred to the professional teams.

\begin{tabular}{|c|c|}
\hline Theme & Participants $(\mathrm{P})$ \\
\hline Beginning Period & $\mathrm{P} 1, \mathrm{P} 2, \mathrm{P} 4$ \\
\hline Basic Education Period & $\mathrm{P} 1, \mathrm{P} 2, \mathrm{P} 3$ \\
\hline $\begin{array}{c}\text { Transition to } \\
\text { Specialization } \\
\text { (Specialized -1) }\end{array}$ & $\mathrm{P} 2, \mathrm{P} 3, \mathrm{P} 4$ \\
\hline $\begin{array}{c}\text { Expertise } \\
\text { (Specialized -II) }\end{array}$ & P1, P3 \\
\hline Performance & $\mathrm{P} 2, \mathrm{P} 3, \mathrm{P} 4$ \\
\hline $\begin{array}{l}\text { Training and } \\
\text { Development }\end{array}$ & $\mathrm{P} 1, \mathrm{P} 2, \mathrm{P} 4$ \\
\hline
\end{tabular}




\section{Theme 1: When the opinions of the participants in the Begining Period Activities are analyzed;}

P2, P4: Participants state that clubs need to structure football academies as an educational institution to create economic resources. In football academies, it is stated that the training of people with advanced football skills necessitates a system approach.

P1, P2: The first childhood period covers the 6-9 age range and this period can be stated as the beginning period of sports. The development of children's physical abilities is important during this period. In this development, swimming and athletics courses should be given to children. In addition, the children should be introduced to the playful shapes of the group.

P1, P4: Children between the ages of 6-12 should be informed about basic movements, coordination, and balance. In addition, focus and discipline should be tried to learn and enjoy the game. For those with proven skills, it is appropriate to give priority to pass and take, hitting and smashing training and small group tactics, one-on-one attack and one-on-one defense.

P2, P4: In the basic development of the child there is an unlimited need for play. Through organized sporting games, children should be brought together with their peers, as well as gaining experience such as obeying rules and decisions, winning and losing pleasure.

In general, participants pointed out that what is important in the 6-12 age group is a child rather than a football. Trainers must organize competitions for children aged 8-9 to win on football pitches. In football training, gymnastics and games should be gained the habit and love of sports. Most of this age range, club lovers should be tried to create the identity of club fans.

P1: In physical education activities including behavior change in children, it is stated that positive interaction between trainer, teacher, child, and parent will contribute to child development. For children aged 6-9, who are capable, it is appropriate to focus on ball mastery and harmony, one-on-one skills and turns.

Stafford (2005) says that games are mostly aimed at building the basic physiological structure and In the game, adaptation to the ball is important, not the rules in this period.

Hill, Dawson, Coutts, and Rowsell (2008) say that is known that the age range for starting football is between 6 and 9 years because the physical ability of the child begins to develop best during this period. Thanks to sports, the child's physical development becomes healthier and the muscles develop. These statements of the author coincide with our findings.

\section{Theme 2: When the views of the participants on the activities of the footballers' Basic Training Period are analyzed;}

P2, P3: Participants want to give importance to the following subjects in basic education for children in the 10-12 age group who are in the transition period to the second childhood and adolescence : player-centered training, versatile sporty basic movement training, coordination and flexibility, learning by playing without positions , Football basic technical training, Fair Play, healthy eating, communication.

Participants emphasize the organization of various social activities that will support the social, psychological and mental development of athletes. Some of these activities include hiking, picnics, sports festivals, tree planting, etc.

P1, P2: Children who seem to have football skills should be introduced to small group tactics, small group combinations, attack and defense principles. In addition, games should be organized to develop special skills under balling and pressure.

P1, P3: The participants draw attention to the determination of the physical inadequacies of children and young people in sports schools. In order to determine the physical deficiencies, health screening (blood tests, ECG, lung screening, dental screening, etc. tests) are carried out without interruption.

P1, P2: For children between 10 and 12 years of age with a proven ability for football, it is appropriate to focus on agility, balance and coordination, strength development and basic strength. In addition, it is useful to work on the development of reflections such as learning to train, watching, reading and playing competition in the subjects of learning.

Eniseler (2010) says that in terms of training, the features revealed in the basic building training section are tried to be transformed into the features desired by certain positions in this period. These statements coincide with our findings.

İsmail \& Tekin state that continuous loadings should be avoided in training and refers to take long breaks to normalize the heart rate between loads. In addition, Technical studies should include playful and close-to-competition forms and recommend the use of gymnastics in training. This approach confirms our findings. 
Theme 3: When the opinions of the participants about the Transition to Specialization ( Specialized-1) Period are analyzed;

P2, P3: The preparation of the transition to the specialization of the age of 13-15 years, the basic principles of football teaching should be focused and the position of the technical-tactical work in the league with the competition should be started.

P4: This period corresponds to the first period of adolescence and defines the beginning period of specialization in sports. It is appropriate to give importance to athletic development, strength development and disability prevention of those who have passed to the sports academy. On technical and tactical issues, it is important to focus on tactics with broad participation, improving game style, quickness, and correct position.

The participants states that football is not only composed of physical - psychomotor features but also psychological cognitive-affective characteristics.

P2-P3 : in this period, emphasizes the importance of the following issues that will enable the development of talent and the necessary personality traits in sports : To create an advanced muscle and skeletal structure, to have high condition ability to make sportive movements, not to break with the desire to succeed in spite of various spiritual, physical and physical disabilities.

Eniseler (2010) states that pre-tactical studies can be entered through simple team sequences in the 13-15 age periods. The author says that it is important to stop the game in the studies and correct the errors and return the heart beats to normal. This approach is close to our findings.

Theme 4: When the views of the participants regarding the Performance Period Activities (Specialized-II) of the Players were analyzed;

$\boldsymbol{P - 1 , P 3}$ : The following subjects should be given importance in the 16-18 age range which is the performance period in sport: Work to improve conditional properties and tactical applications in the competition environment.

P1: The period of 16-18 years should be considered as the first steps of professionalism and it is important to continue the development of physical power and to learn the psychological factors affecting performance. In addition, under pressure, gain, strength, speed, power and condition issues should be emphasized.

$\boldsymbol{P}$-3: He emphasized the importance of the issues related to training phases and durations, tournaments, age groups, and health management. At the same time, technical and tactical issues should be given importance and the time to play according to the rules of the game should be emphasized.

Martindale, Collins, and Abraham (2007) say that In performance training, the physiological standards of football are tried to be reached. Other factors that affect performance are considered. These statements of the author are in line with our findings.

Theme 5: When the views of the participants about the skill development of the players and the Preparing for Professional Life (Performance - 18 years and beyond) were analyzed;

P2, P4: It is important to transfer the players raised in the Football Academies to the A team and to sell the surplus ones.

P2: Young people should be prepared for the transition to professional life as a trained football player. from this age period, the player is aware of the fact that he has chosen this job as a profession.

P3: In accordance with the management of training and matches, training planning, training periodization and giving tactical notion should be given importance.

Eniseler (2010) states that training should be performed in a unified (technical + tactical + condition) tempo under matched conditions. The author states that players should pay attention to the issues in their private life (sleep order and nutrition) that will directly affect their professional life. These explanations confirm our findings.

\section{Theme 6: When the views of the participants about the Transition to Professionalism were analyzed;}

P1: This period includes the issuance of professional licenses of young people who have completed their standards. In this period, the player's opinion should be fully professionalized. the higher the efficiency level of the performance athlete, the more he will live in good conditions.

P2, P4: Football players who have undergone academic education and who have reached the highest level of standards should be provided to be in the A teams firstly and if this is not possible, they should be sent to lower leagues or other clubs as rented in order to improve their performance.

Ferguson and Moritz (2013) state that players who have undergone academic training and have reached the age of 18 
should be aware of developing their abilities after having sufficient knowledge of their physical capabilities and abilities. These explanations were considered as a discourse close to our findings.

\subsection{Conclusion}

Participants state that in order to create economic resources like a business in their clubs, football academies need to structure very well as an educational institution because it will be possible to transfer players from football academies, which are the only source of income, to team A as a cheaper economic resource, and to sell them to other clubs in need.

Participants state to require a systematic approach to training people with advanced football skills over a wide age range. Barton, Emery, Flood, Selsky, and Wolstenholme (2004) state that the system approach remains up-to-date within modern management approaches. Process management can be best implemented within the system approach. Pourdehnad and Robinson (2001) say that more specifically, system approach and process management support each other.

It is clear that sports clubs, which are sportive businesses, need to create their own economic resources that will ensure the continuity of sporting success in order to survive. When the income of the clubs is analyzed, it is seen that this resource can be provided by club football academies most economically.

The participants state that football is not only composed of physical - psychomotor features but also comprehensively covers a wide range of psychological-cognitive-affective characteristics. Eniseler (2010) said that Football, which has a close relationship with sports sciences, also states that it is a sports branch with very different characteristics such as Technical, Tactical, Conditional, Psychological, Health, and Nutrition.

Participants state that the Football Federation has formed youth development leagues for youth development periods According to this league structuring, the training in the Academy should be considered as (6 - 12 years), (13-15 years) and (16-18 years), (19- and after).

Human development is an ongoing process starting from fertilization to adolescence These ages in developmental stages vary according to different sources ( www.cadempsikoloji.com ) and (İsmail \& Tekin, 2004)

- the first 2 years after birth, infancy,

- 3-6 years of age, the first childhood (play),

- 7-11 years of age the second chilhood of primary school,

- 11-12 years of age, the transition to adolescence and

- 12-18 years of age is considered adolescence

In general, the participants pointed out that in the 6-12 age group it is not the football but the child. In particular (6-9 years of age) in parallel with the development of children's physical abilities, it is important to benefit from a wide range of play forms. Strudwick and Reilly (2001) state that the football game has a structure that requires different speed and movement, which requires long and complex physical-physiological characteristics in terms of activity quality and playing time.

Participants state that basic movements, coordination, and balance are important in this age period and they emphasize the importance of learning to focus on discipline and enjoyment. In addition, for those who have the ability to be identified, it is appropriate to give priority to pass and take, hitting training and small group tactics, one-on-one attack and one-on-one defense. Eniseler (2010) points out that it is important to have children together with their peers through sports games to be held and to try to gain experiences such as obeying rules and decisions, defeating and absorbing defeat.

Participants, In particular, they wish to organize tournaments and competitions aimed at winning children on the football fields for children aged 8-9 years. It is aimed to gain the habit and love of doing sports with movements and games towards gymnastics education. It mentions the focus on ball mastery and harmony, one-to-one skills and turns between the ages of 6-9 to children with Soccer Ability identified by their coaches.

Hill, Dawson, Coutts, Rowsell (2008) state that it is known that the age range for starting football is between 6 and 9 years because the physical ability of the child begins to develop best during this period. Thanks to sports, the child's physical development becomes healthier and the muscles develop.

Participants emphasize that player-centered education, multifaceted sport basic movement training, coordination and flexibility, learning by playing without position discrimination, football basic technical training, Fair Play, healthy nutrition, communication should be given importance to children between the ages of 10-12.

The participant said that for children with football skills, it is appropriate to focus on agility, balance and coordination, 
strength development and basic strength. In addition, it is useful to work on the development of reflections such as learning to train, watching, reading and playing in competition. Stafford (2005) says that in this period, games are mostly aimed at building the basic physiological structure. In the game, adaptation to the ball is important, not the rules.

The participants state that the main principles of football should be emphasized in the age range of 13-15 and that special technical and tactical studies should be started in the leagues. It is appropriate to give importance to athletic development, strength development and disability prevention of those who have passed from sports school to academia. On technical and tactical issues, it is important to focus on broad-based tactics, game style development, promptness, and correct positioning.

Neuromuscular training (NT) program, which is current information that is not brought up by the participants but which appeared in the literature review, is thought to be included in the training programs from the age of 11 years. According to this definition, agility, balance, plyometrics, power, stability, and strength training are subsets of NT. (Myer et al. (2011b)

The participants state that the activities aimed at improving their conditional characteristics in the 16-18 age range and the tactical applications in the competitive environment are emphasized. In tactical exercises: preliminary tactical exercises can be performed by playing games according to certain simple sequences. Eniseler (2010) says that Coaches should give importance to technical and tactical issues in this age period and should focus on playing time according to the rules of the game.

Participants say that the period of 16-18 years should be considered as the first steps of professionalism and it is important to continue the development of physical power and to learn the psychological factors affecting performance. In addition, under pressure, gain, strength, speed, power and condition issues should be emphasized. The training must pass in integrity (technical + tactical + condition) and tempo under match conditions. (Eniseler,2010)

Participants state that as a trained footballer, young people aged 18 and over should prepare for participation in professional Leagues and transition to professional life. Ferguson and Moritz (2013) state that players who have undergone academic training and have reached the age of 18 should be aware of developing their abilities after having sufficient knowledge of their physical capabilities and abilities. These explanations were considered as a discourse close to our findings.

Last of all, if football academies are managed in accordance with the process management within the system approach, football players will be trained in accordance with the requirements of the era.

\section{References}

Aalst, H., \& Weske, M. (2003). Business Process Management: A Survey. In W. M. P. v. d. Aalst \& M. https://doi.org/10.1007/3-540-44895-0

Akşar, T. (2013). Krizdeki Futbol', Literatür Yayınc1lık,1 nci bask1,

Akşar, T., Kutlu, M., \& Devecioğlu, S., (2018). Futbol Yönetimi, Literatür Yayın Evi, , , 9789750404399.

Antonucci, Y. L., \& Goeke, R. J. (2011). Identification of appropriate responsibilities and positions for business process management success, Business Process Management Journal, 17(1), 127-146. https://doi.org/10.1108/14637151111105616

Arregui, P. A. N. (2001). El modelo del sistema viable - MSV: experie^ncias de su aplicacio'n en Chile, unpublished Master theses, Universidad de Santiago, Santiago de Chile.

Balyi, I. ( 2002). Long term athlete development: the system and solutions. Faster Higher Stronger; 14, 9-1

Behringer, M., Vom Heede, A., Yue, Z., \& Mester, J., (2010). Effects of resistance training in children and adolescents: a meta-analysis. Pediatrics, 126, e1199-210. https://doi.org/10.1542/peds.2010-0445

Benedict, T., Champlin, B., Downing, B. D., Franzen, J., \& Raschke, R. L. (2009). Business Process Management Common Body Of Knowledge.CreateSpace Independent Publishing Platform

Bloomfield, J., Polman, R., \& O’Donoghue, P. (2007). Physical demands of different positions in FA Premier League Soccer. "Science and Football VI (EDITED BY T Reilly, F. Korkusuz )Londo-Routledge, 175-181.

Bulduk, S., Şanlıer, N., \& Demircioğlu, Y. (2000). Ankara'da Yaz Spor Okuluna Devam EdenAdölasanların Beslenme Durumlarının Saptanması. Gazi Beden Eğitimi ve Spor Bilimleri KongresiBildiriler; 26-27.

Chtara, M., Chamari, K., Chaouach, M., Chaouachi, A., Koubaa D., Feki,Y., Millet, G., \& Amri, M. (2005). Sports Med., Effects of intra-session concurrent endurance and strength training sequence on aerobic performance and capacity Aug; 39(8), 555-560. https://doi.org/10.1136/bjsm.2004.015248 
Devecioğlu, S. (2018). Futbolda Özerkliğin Ekonomisi, Spor Yayınevi ve Kitabevi, 152, 978-605-68400-7-4

Doğan, Ö. (2013). Süreç Tasarımı ve Süreçlerle Yönetim, Paradigma Akademi,İzmir.

Eniseler,N.(2010). Bilimin 1şı̆̆ında Futbol Antrenmanı, Birleşik Matbacılık,İzmir

Ferguson, A., \& Mortitz, M. (2013), Liderlik,Pegasus Yayınevi, İstanbul

Franz, K. (2012). Value-driven business Process Management - The Value-Switch for LastingCompetitive Advantage, McGraw-Hill, New York, e.a.

Hammer, M. (2002). Process management and the future of six sigma. MIT Sloan Management Review, 43(2), 26, 32. https://doi.org/10.1109/EMR.2002.1167284

Hammer, M. (2010). What is business process management? In J. v. Brooke \& M. Rosemann (Eds.), Handbook on business process management 1 (pp. 3: 16). Springer Berlin. https://doi.org/10.1007/978-3-642-00416-2_1

Harmon, P. (2011). Capabilities and processes (Tech. Rep.). Retrieved 2013-07-04, from:http://www.bptrends.com/publicationfiles/07-12-2011

Heidelberg \& Harmon, P. (2010). The Scope and Evolution of Business Process Management. In J. v. Brocke. https://doi.org/10.1007/978-3-642-00416-2_3

Hill-Haas, S, Dawson, B., Coutts, A., \& Rowsell, G. (2008). Physiological responses and time-motion characteristics of various small-sided soccer games in youth players. J. Sports Sci., 27(1), 1-8.

https://doi.org/10.1080/02640410802206857

Jeston, J., \& Nelis, J. (2006). Business Process Management: Practical Guidelines to Successful Implementations (1st ed.). Butterworth-Heinemann.

Jeston, J., \& Nelis, J. (2008). Management by process a roadmap to sustainable business process managementAmsterdam; Boston: Elsevier/Butterworth-Heinemann.

https://doi.org/10.1016/B978-0-7506-8761-4.00010-X

Kale, R. (2017). Antrenman Bilgisi , Gelişim Üniversitesi Yayınları, 1nci baskı, İSTANBUL.

Kilmann, R. (1995). A holistic program and critical success factors of corporate transformation. European Management Journal, 13(2), 175-186. https://doi.org/10.1016/0263-2373(95)00005-6

Kirchmer, B. (2015). The Process of Process Management - Mastering the New Normal in a Digital World. In: BMSD Proceedings, July 2015. (in publication). https://doi.org/10.1007/978-3-319-40512-4_10

Köklü, Y., Özkan, A., Alemdaroğlu, U., \& Ersöz, G. (2009). Genç Futbolcuların Bazı Fiziksel Uygunluk ve Seatotip Özelliklerinin Oynadıkları Mevkilere Göre Karşılaştırılması Spormetre Beden Eğitimi ve Spor Bilimleri Dergisi, 7(2), 61-68. https://doi.org/10.1501/Sporm_0000000151

Martindale, R., Collins, D., \& Abraham, A. (2007). Effective talent development: the elite coach perspective in UK sport. J Appl Sport Psychology; 19(2), 187-206. https://doi.org/10.1080/10413200701188944

Mayıs Çetin, C., Akın, B., \& Erol, V. (2001). Toplam Kalite Yönetimi ve Güvence Sistemleri (ISO9000: 2000-Revizyonu), Beta-Yayıncılık, İstanbul.

Mingers, J., \& White, L. (2010). A review of the recent contribution of systems thinking to operational research and management science, European Journal of Operational Research, 207(3), 1147-1161. https://doi.org/10.1016/j.ejor.2009.12.019

Musa, Ö., \& İsmail, S. (2010). Türk Kamu Yönetiminde Bilgi Sistemleri ve E-dönüşüm,Eğitim Kitabevi, Konya, 25.

Myer, G. D., Faigenbaum, A. D., Ford, K. R., Best, T. M., Bergeron, M. F., \& Hewett, T. E. (2011b). When to Initiate Integrative Neuromuscular Training to Reduce Sports-Related Injuries and Enhance Health in Youth? Curr Sports Med Rep, 10, 155-166. https://doi.org/10.1249/JSR.0b013e31821b1442

Ould, M. A. (2005). Business Process Management: A Rigorous Approach. Meghan Kier Pr.

Özgür, K., \& Hande, K. (2009). Belge Yönetiminde Program Geliştirme: Belge Yönetimi Kapasite Değerlendirme Sistemi, Bilgi Dünyast, 10(2), 269.

Pourdehnad, J., \& Robinson, P. J. (2001). Systems approach to knowledge development for creating new products and services, Systems Research and Behavioral Science, 18, 29-40. https://doi.org/10.1002/sres.365

Samur, S. (2013). Kurumsal Futbol Yönetimi (Futbol ama Hangi Futbol), Gazi Kitapevi, Ankara.

Samur, S. (2018). Bilgi Çağında Spor Yönetimi, Gazi Kitapevi, Ankara. 
Sharp, A. (2009). Work of modeling: tools for process improvement and applications development Boston:Artech House. (2nd ed.).

Skarzauskiene, A. (2010). Managing complexity: systems thinking as a catalyst of the organization performance, Measuring Business Excellence, 14(4), 49-64. https://doi.org/10.1108/13683041011093758

Smart, P. A., Maddern, H., \& Maull, R. S., (2009). Understanding business process management: Implications for theory and practice. British Journal of Management, 20(4), 491-507. https://doi.org/10.1111/j.1467-8551.2008.00594.x

Smart, P. A., Maull, R. S., Childe, S. J., \& Radnor, Z. J. (2004). Capitalizing on thematic initiatives: a framework for process-based change in SMEs. Production Planning \& Control, 15(1), 2-12. https://doi.org/10.1080/09537280310001649363

Stafford, I. (2005). Coaching for long-term athlete development: to improve participation and performance in sport. Leeds (UK). Ed. The National Coaching Foundation;

Strudwick, T., \& Reilly, T. (2001). Work-rate profiles of elite Premier League football players Insight: the FA Coaches Association Journal.

Swenson, I., \& Rosing, V. (2015). What is Business Process Management? In: von Rosing, M., Scheer, A.-W., von Scheel, H.: The complete Business Process Handbook - Body of Knowledge from Process Modelingto BPM, Volume 1, Amsterdam, Boston, e.a., 79.88. https://doi.org/10.1016/B978-0-12-799959-3.00004-5

TFF development leagues status: (www.tff.org)

Topkaya, İ., \& Tekin, A. (2004). Futbol Genel Kuramsal Bir Çerçeve ve Teknik ve Temel Taktik Öğretim, Nobel Yayın Dağıtım.

Weske, M. (2007). Business Process Management: Concepts, Languages, Architectures.Springer Berlin Heidelberg

Yıldırım, A., \& Şimşek, H. (2005). Sosyal Bilimlerde Nitel Araştırma Yöntemleri, Seçkin Yayınları, Ankara

www.uefa.com

www.gosh.nhs.uk/medical information

www.cadempsikoloji.com/blog/posts/cocuk-gelisim-donemleri

\section{Copyrights}

Copyright for this article is retained by the author(s), with first publication rights granted to the journal.

This is an open-access article distributed under the terms and conditions of the Creative Commons Attribution license which permits unrestricted use, distribution, and reproduction in any medium, provided the original work is properly cited. 